\title{
Ber-EP4: new monoclonal antibody which distinguishes epithelia from mesothelia
}

\author{
U Latza, G Niedobitek, R Schwarting, H Nekarda, H Stein
}

\begin{abstract}
A new monoclonal antibody, Ber-EP4, directed against a partially formol resistant epitope on the protein moiety of two 34 kilodalton and 39 kilodalton glycopolypeptides on human epithelial cells is described. Immunostaining of a wide range of normal and neoplastic human tissues and cell lines showed that all carcinomas and all non-neoplastic epithelial cells, except hepatocytes, parietal cells, and apical cell layers in squamous epithelia, homogeneously expressed BerEP4 antigen. As Ber-EP4 does not detect any normal or neoplastic non-epithelial cells, this antibody might prove valuable for the differentiation of the following (i) non-epithelial tumours from undifferentiated carcinomas; (ii) hepatocytes from bile duct cells in certain liver diseases; (iii) mesothelial cells from carcinoma cells in lung biopsy specimens; and (iv) reactive mesothelial cells from carcinoma cells in smears of serous effusions.
\end{abstract}

Differential diagnosis of anaplastic carcinoma and poorly differentiated tumours of nonepithelial origin is a common problem in surgical pathology. Advances have been made in this respect by immunohistochemical methods ${ }^{1-3}$ using monoclonal antibodies such as anti-cytokeratin reagents, ${ }^{4-6}$ but different intermediate filaments are occasionally coexpressed in given cells. ${ }^{7-11}$ In cell separation or flow cytometry, for example, the exclusively cytoplasmic localisation of cytokeratins causes difficulties. Monoclonal antibodies directed against epithelial surface antigens, such as carcinoembryonic antigen (CEA) and related antigens, ${ }^{12}$ or epithelial membrane antigen (EMA), ${ }^{13}$ are of limited value for the differential diagnosis between epithelial and nonepithelial tumours. These antigens are not expressed in all epithelia, their expression in a given tumour is often heterogeneous, leading to unreliable results in small biopsy specimens, ${ }^{14}$ and they may be expressed in non-epithelial cells. ${ }^{15}$ In particular, it is often impossible to discriminate reactive mesothelial cells and mesotheliomas from carcinoma cells with available antibodies, though this is of great diagnostic importance. As no strictly mesothelial cell specific monoclonal antibodies exist expression of cytokeratins and lack of CEA expression are used as indicators of mesothelial origin. Not all carcinomas, however, are detected by anti-CEA monoclonal antibodies, and intermediate filament expression in mesothelia can vary. ${ }^{16} \mathrm{We}$ describe the use of a monoclonal antibody Ber-EP4 directed against an epithelium specific membrane antigen absent from mesothelial cells and compare it with the monoclonal antibody HEA125. ${ }^{17} 18$

\section{Methods}

Cell lines MCF-7, MDA-MB-231, MDAMB-175, BT-20, MOLT-4, RD and Daudi were obtained from the American Type Culture Collection (Atlanta, Georgia, USA). ASPC-1, AlAb, and COLO 357 were a kind gift from Dr Knuth, Mainz, West Germany, ${ }^{19}$ Co. and Ho. were kindly supplied by Dr D Jones (Southampton, England, ${ }^{20}{ }^{21}$ and L540, L428, and L591 by Dr V Diehl, Cologne, West Germany. $^{22} 23$

Rabbit anti-mouse immunoglobulin sera for immunocytological staining and monoclonal antibody C3D-1 were from Dakopatts, Copenhagen, Denmark, KL1 was from Dianova, Hamburg, West Germany and HEA125 from Progen Heidelberg, West Germany.

Diagnostic biopsy specimens were routinely processed or snap frozen in liquid nitrogen and stored at $-80^{\circ} \mathrm{C}$. For immunostaining, frozen sections were fixed in acetone/chloroform and stained with the alkaline phosphatase-antialkaline phosphatase (APAAP) procedure. ${ }^{24} 25$ Cytospins and smears were fixed in acetone. Cell lines with endogenous alkaline phosphatase were stained with immunoperoxidase. ${ }^{26}$

Monoclonal antibodies were obtained using established methods from mice immunised with MCF-7 cells. ${ }^{27}{ }^{28}$ Hybridoma supernatant were screened for anti-epithelial reactivity immunocytochemically and absence of anticytokeratin reactivity in immunoblotting experiments (data not shown). The Ig subclass was determined by double immunodiffusion using specific anti-mouse Ig reagents (Serotec, Wiesbaden, West Germany).

\section{IMMUNOPRECIPITATION}

For surface radioiodination, MCF-7 cells were labelled by the lactoperoxidase technique. ${ }^{29}$ For internal labelling, MCF-7 cells were incubated for two or 24 hours with ${ }^{35} \mathrm{~S}$-methionine (NEN- Dupont, Dreieich, West Germany). ${ }^{30}$ Immunoprecipitation was carried out with goat anti-mouse agarose beads coated with Ig (Sigma). ${ }^{31}$ Precipitates were analysed on $12.5 \%$ polyacrylamide sodium dodecyl sulphate gel electrophoresis (SDS-PAGE). ${ }^{32}$ An 


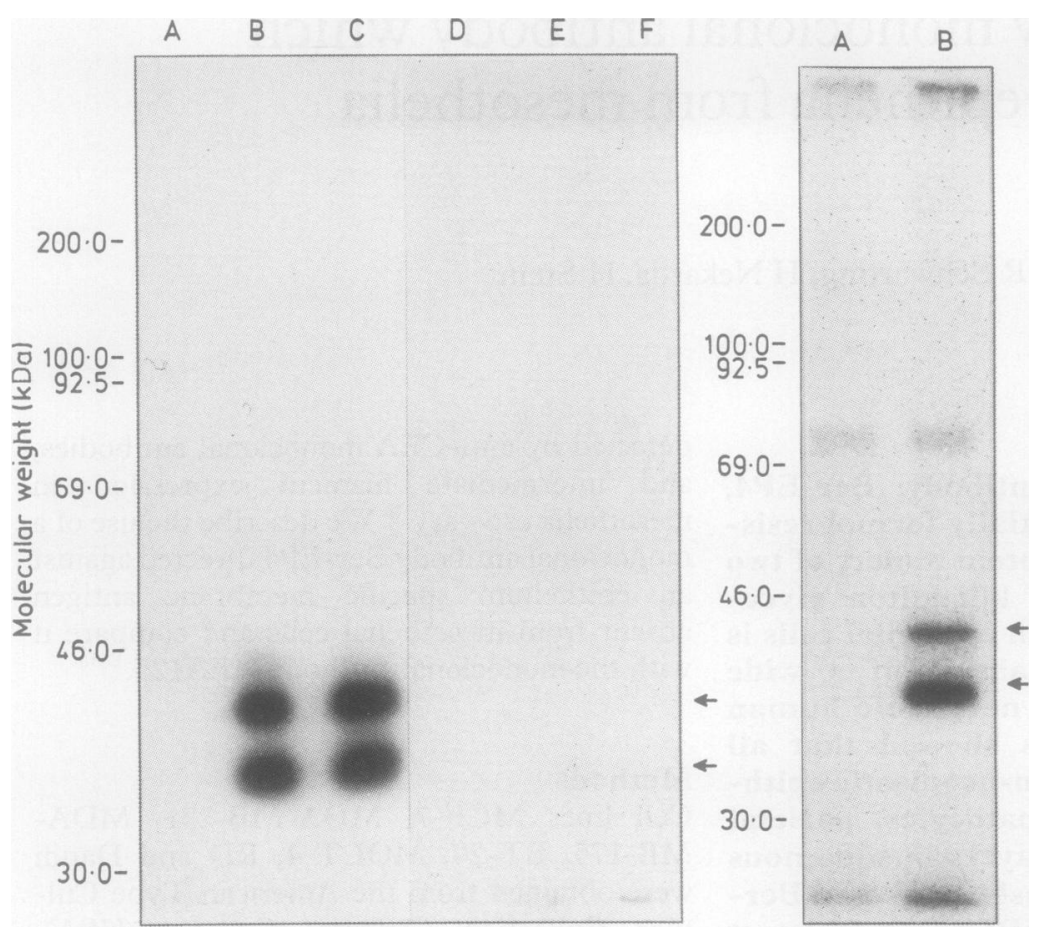

Figure 1a Immunoprecipitation of Ber-EP4 antigen from ${ }^{125}$ I surface labelled MCF-7 cell line. Immunoprecipitates were analysed with SDS PAGE under reducing conditions. Negative control precipitate (lane A), Ber-EP4 precipitate (lane $C$ ), $H E A 125$ precipitate (lane $B$ ); sequential precipitates (lanes $D, E, F$ ) of $H E A 125$ after Ber-EP4 precipitation (lane D), of Ber-EP4 after HEA125 precipitation (lane $E$ ), of negative control precipitate (lane $F$ ).

Figure $1 b$ Immunoprecipitation of Ber-EP4 antigen from ${ }^{125}$ I labelled MCF-7 cell line under non-reducing conditions. Negative control precipitate (lane A), Ber-EP4 precipitate (lane B).

Figure 2

Immunoprecipitation of

Ber-EP4 antigen at two

hours (lanes $A, B, C$ ) and

24 hours (lanes $D, E, F$ )

${ }^{35} S$ methionine labelled

$M C F-7$ cell line.

Molecular weight was

determined with SDS

$P A G E$ under reducing

conditions. Lanes $A$ and $F$

show negative control

precipitates, lanes $C$ and

$D$ Ber-EP4 precipitates,

and lanes $B$ and $E$ Ber-

EP4 precipitates after

edoglycosidase $F$ cleavage. unrelated antibody of the same subclass served

For deglycosylation, precipitates were boiled in reducing sample buffer without bromophenol blue and digested overnight with $48 \mathrm{U} /$ $\mathrm{ml}$ endoglycosidase $\mathrm{F}$ (Boehringer, Mannheim, West Germany) at room temperature. ${ }^{18} 34$ as a control. ${ }^{33}$
CHEMICAL AND ENZYMATIC TREATMENT

Periodate oxidation ${ }^{35}$ was carried out with $0.1 \mathrm{M}$ sodium periodate (Sigma) in $0.05 \mathrm{M}$ sodium acetate buffer, $\mathrm{pH} 4.5$, at $4^{\circ} \mathrm{C}$ for one hour in the dark on cryostat sections fixed in Zamboni's reagent. ${ }^{36}$ For enzyme digestion, cryostat sections fixed in acetone were incubated with $0.1 \mathrm{mg} / \mathrm{ml}$ pronase $\mathrm{E}$ (Sigma) in phosphate buffered saline for one to 60 minutes at $37^{\circ} \mathrm{C}$. For dot blot experiments, MCF-7 lysates were adsorbed to nitrocellulose membrane and treated with periodate or pronase $\mathrm{E}$ (10 $\mathrm{mg} / \mathrm{ml}, 37^{\circ} \mathrm{C}$, overnight). After incubation, immunostaining was performed. An irrelevant antibody of the same subclass served as a negative control. KLl monoclonal antibody directed against a protein epitope and C3D-1 monoclonal antibody directed against a carbohydrate (CD15) epitope served as positive controls.

\section{COMPETITIVE INHIBITION OF BER-EP4 AND}

HEA 125

Monoclonal antibodies were purified with Affi-Gel (Bio-Rad, Munich, West Germany). Purified antibodies $(1 \mathrm{mg} / \mathrm{ml}$ in $0.1 \mathrm{M}$ sodium carbonate buffer, $\mathrm{pH}$ 9) were fluorescein isothiocyanate (FITC) labelled by incubation with $10^{\circ}{ }_{0} \mathrm{v} / \mathrm{v}$ FITC solution $(1 \mathrm{mg} / \mathrm{ml}$ FITC (Sigma) in DMSO (Merck)) for three hours in the dark with agitation and subsequent dialysis. Indirect immunofluorescence staining was performed as described previously. ${ }^{31}$ For competitive inhibition, cells were preincubated with unlabelled antibody at concentrations ranging from $10^{-5}$ to $1 \mathrm{mg} / \mathrm{ml}$, directly stained with FITC-labelled primary antibody, and analysed in an EPICS 752 (Coulter Electronics, Krefeld, West Germany). Irrelevant FITC-labelled antibodies and irrelevant cell lines served as negative controls.

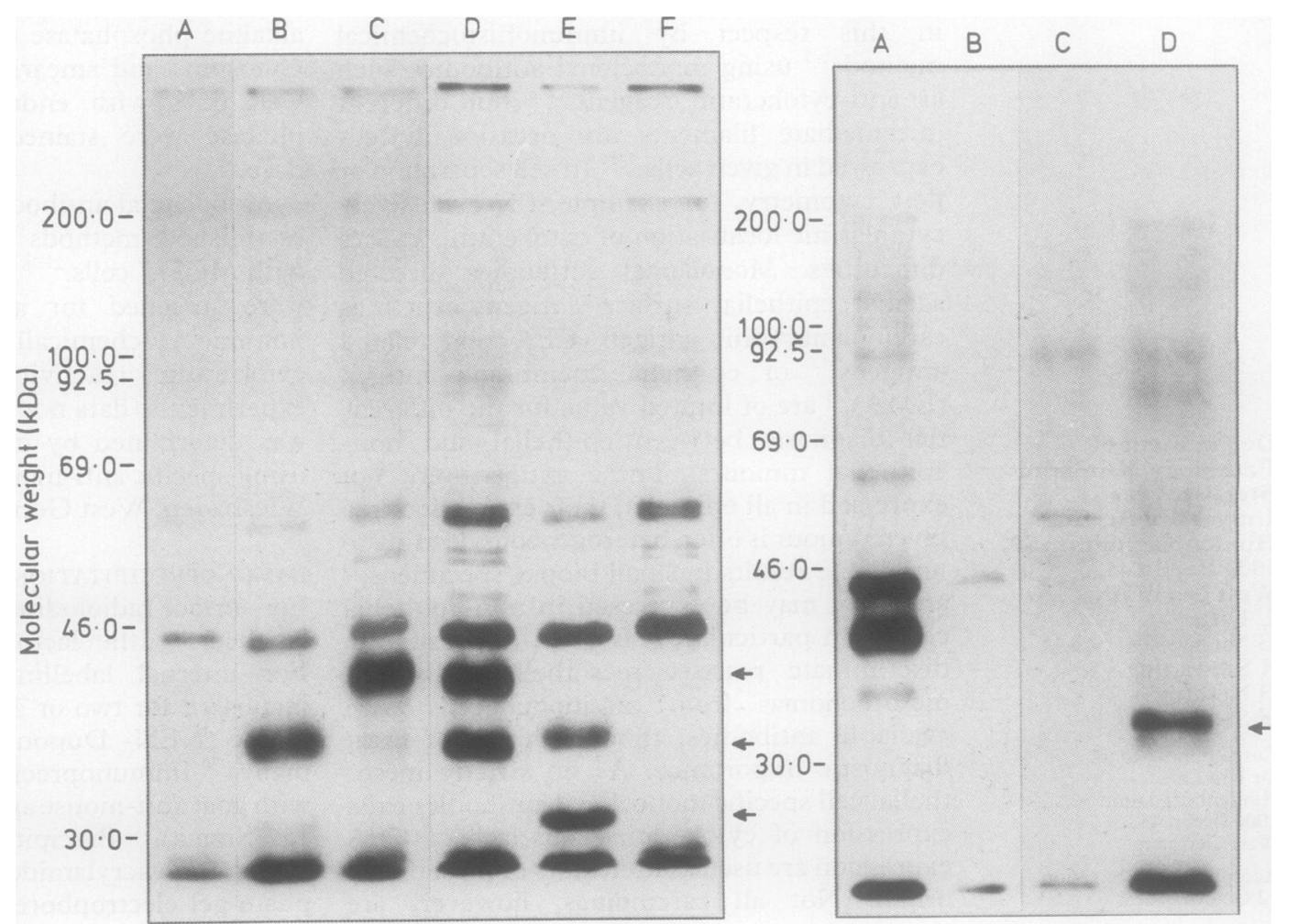




\section{Results}

BIOCHEMICAL CHARACTERISATION OF THE BEREP4 ANTIGEN

Two polypeptides were precipitated under reducing conditions from ${ }^{125} \mathrm{I}$ surface-labelled MCF-7 cells, one chain with an apparent molecular weight of 34000 and, with varying intensity, another chain of 39000 (figure 1a). Under non-reducing conditions the molecular weight was slightly higher (39000 and 44000 ) (figure 1b). Internal labelling of MCF-7 and K562 cell lines with ${ }^{35} \mathrm{~S}$-methionine for 24 hours yielded the same results (figure 2). After two hours of labelling, however, only one chain of 39 kilodaltons could be precipitated, both under reducing and non-reducing conditions. Deglycosylation of the precipitate reduced the molecular weight from 39000 and 34000 to 36000 and 31000 , respectively (figure 2 ).

On cryostat sections of breast carcinoma mild protease treatment before immunostaining diminished reactivity with Ber-EP4; staining was unaffected by periodate oxidation. Stronger protein cleavage applied in dot blot experiments led to a complete loss of reactivity with Ber-EP4.
IMMUNOHISTOCHEMICAL STAINING WITH BEREP4

Immunostaining of a panel of different normal tissues with Ber-EP4 (table 1) showed that all normal epithelial tissues expressed the BerEP4 antigen on the membrane, preferentially basolaterally (figure 3), and in the cytoplasm. Only parietal cells in gastric glands and apical cell layers in squamous epithelia were negative. Adult hepatocytes, in contrast to fetal hepatocytes, did not express the antigen.

Epithelial cells of different origin displayed varying levels of Ber-EP4 antigen expression, while epithelial cells of one type always expressed the antigen homogeneously. Most epithelia were strongly positive. The Ber-EP4 antigen was not expressed in non-epithelial cells. Pleura and peritoneum lining cells were negative, but cells covering the ovary displayed slight positivity.

Cytospins of a total of 37 cell lines of various origin were investigated. All carcinoma cell lines were homogeneously stained with BerEP4 (table 2). All non-epithelial cell lines were negative except for the erythromyeloid cell line K562.
Figure 3

Immunohistochemical reactivity of monoclonal antibody Ber-EP4 ( APAAP, haematoxylin counterstain, frozen sections if not indicated otherwise):

(a) Mammary gland: strong cytoplasmic and preferably basolateral membrane staining of ductal cells. Myoepthelial cells, fat and connective tissue components remain unstained.

(b) Stomach: staining of glandular and chromaffin cells while parietal cells remain unstained (arrow). (c) Malignant mesothelioma of pleura: no staining of tumour cells.

(d) Same case as c: staining of tumour cells with comparative

monoclonal antibody $K L 1$.
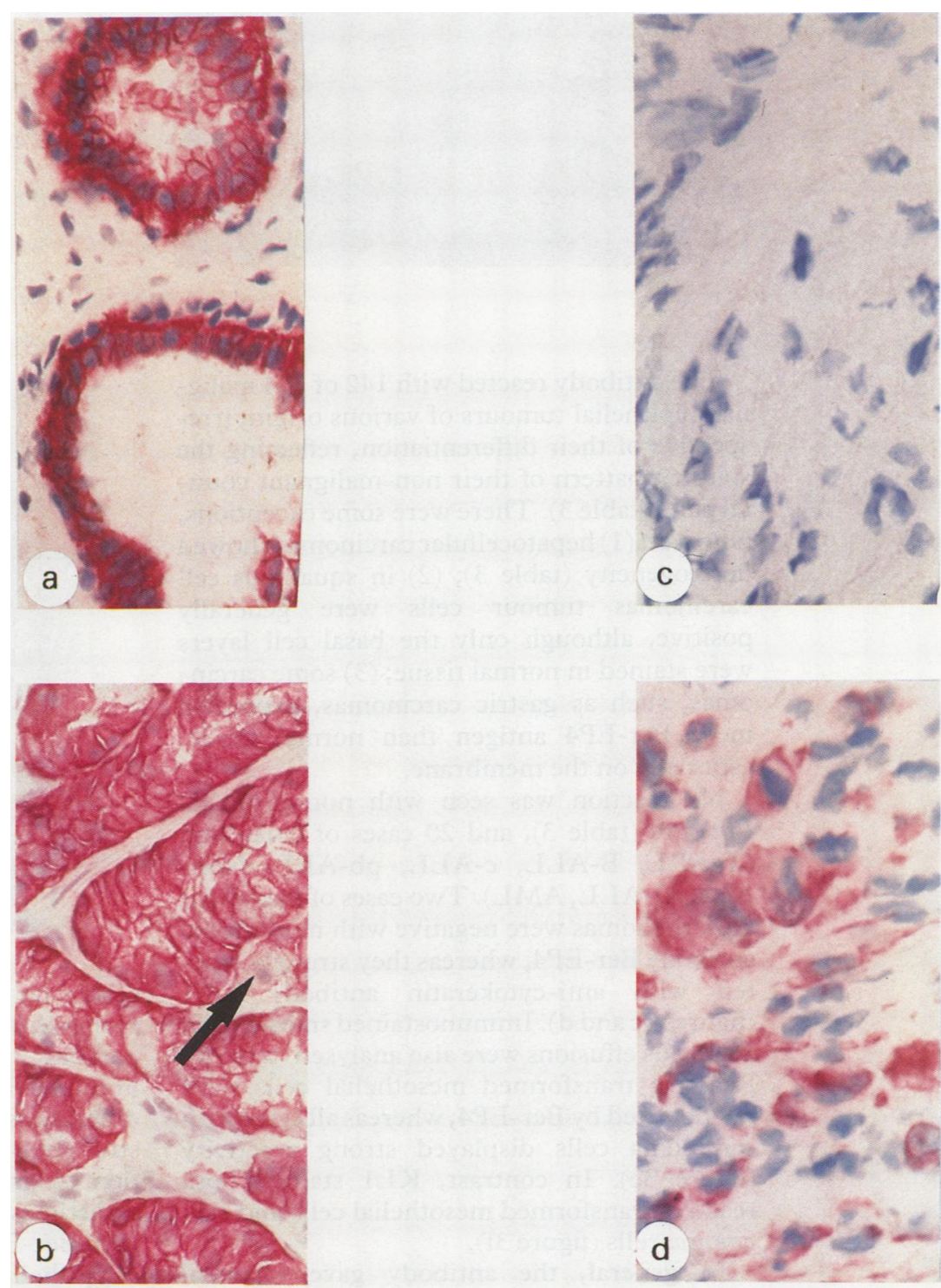
(e) Smear of pleural effusion: staining of mammary carcinoma cells, no staining of reactive mesothelial cells.

(f) Same case as e: staining of carcinoma cells and reactive mesothelial

cells with comparative

monoclonal antibody $K L 1$.

(g) Liver: no staining of hepatocytes and strong

staining of bile duct cells.

(h) Fetal liver: staining of hepatocytes.

(i) Liver after hepatitis $B$ infection: staining of hepatocytes adjacent to portal tracts and only weak staining of bile duct cells (paraffin wax embedded section).
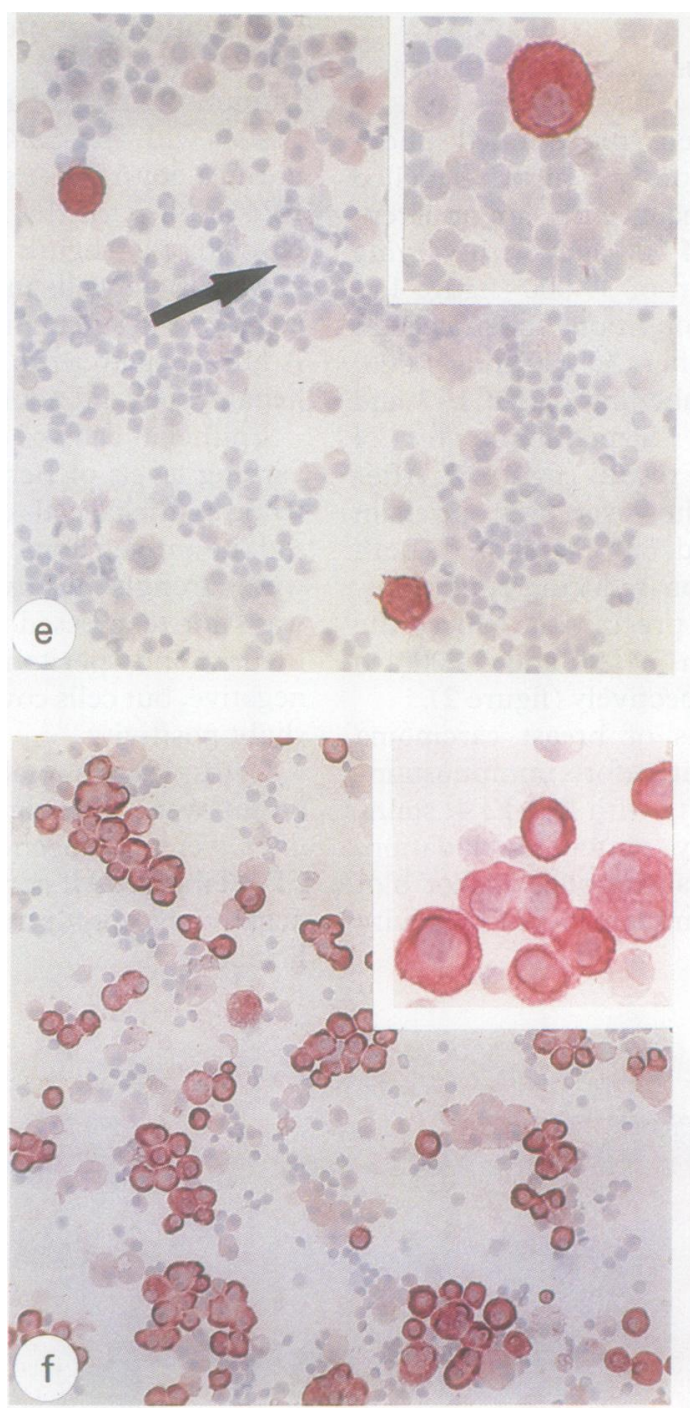

The antibody reacted with 142 of 144 malignant epithelial tumours of various origin, irrespective of their differentiation, reflecting the staining pattern of their non-malignant counterparts (table 3). There were some exceptions, however: (1) hepatocellular carcinomas showed heterogeneity (table 3 ); (2) in squamous cell carcinomas tumour cells were generally positive, although only the basal cell layers were stained in normal tissue; (3) some carcinomas, such as gastric carcinomas, expressed more Ber-EP4 antigen than normal tissue, especially on the membrane.

No reaction was seen with non-epithelial tumours (table 3 ), and 20 cases of leukaemia (T-ALL, B-ALL, c-ALL, pb-ALL, NonALL, O-ALL, AML). Two cases of malignant mesotheliomas were negative with monoclonal antibody Ber-EP4, whereas they strongly reacted with anti-cytokeratin antibody $\mathrm{KLl}$ (figures $3 \mathrm{c}$ and d). Immunostained smears from 36 serous effusions were also analysed (table 4). Reactive transformed mesothelial cells were not detected by Ber-EP4, whereas all cases with carcinoma cells displayed strong reactivity (figure $3 \mathrm{e}$ ). In contrast, KLl stained both reactive transformed mesothelial cells and carcinoma cells (figure $3 \mathrm{f}$ ).

In general, the antibody gave identical
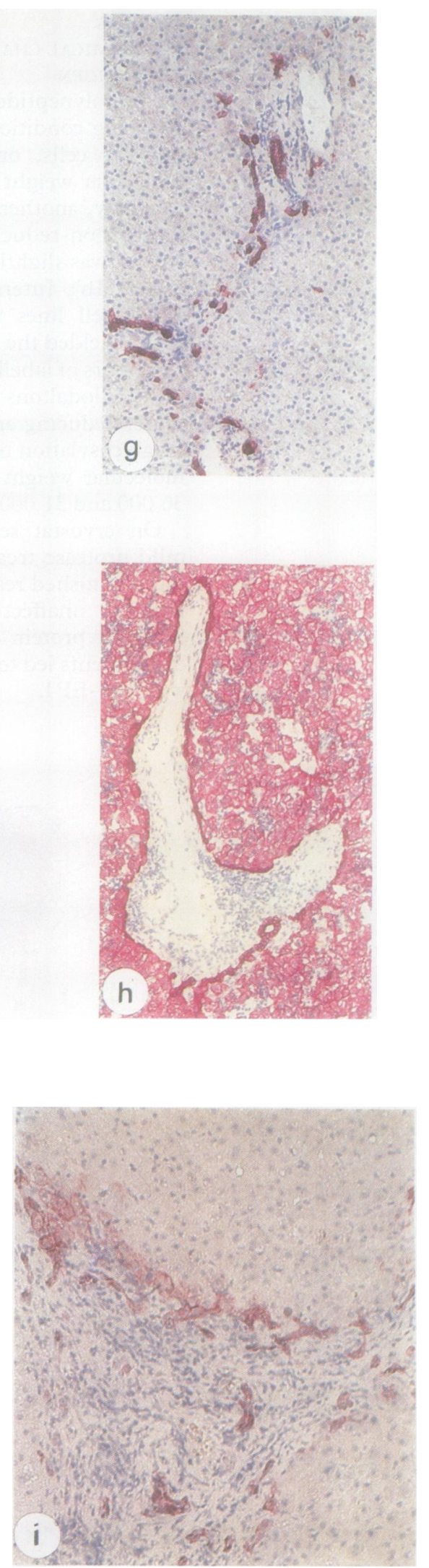

results on cryostat and paraffin wax embedded sections, irrespective of pronase digestion of paraffin wax embedded sections before immunostaining (table 1). There were some differences, however: reactions were often stronger on cryostat sections; prolonged fixation of tissue (more than 48 hours) led to a sometimes complete reduction of reactivity with Ber-EP4.

Epithelial cells containing large amounts of 
Table 1 Reactivity of Ber-EP4 with normal human frozen $(F)$ and paraffin wax embedded $(P)$ tissues

\begin{tabular}{|c|c|c|}
\hline \multirow[b]{2}{*}{ Tissue } & \multicolumn{2}{|c|}{ Reactivity } \\
\hline & $F$ & $P$ \\
\hline $\begin{array}{l}\text { Epithelia glands: } \\
\text { Salivary glands } \\
\text { Pancreas: ducts, endocrine + exocrine glands } \\
\text { Thyroid gland: thyrocytes, C cells } \\
\text { Parathyroid gland } \\
\text { Adrenal gland: cortical epithelium } \\
\text { Pituitary gland: adenohypophyseal cells } \\
\text { Mammary gland: acini, ducts } \\
\text { Prostate: glandular epithelia } \\
\quad \text { duct cells }\end{array}$ & $\begin{array}{l}+ \\
+ \\
+ \\
+ \\
+ \\
+ \\
+ \\
+ \\
+\end{array}$ & $\begin{array}{l}\text { ND } \\
+ \\
+ \\
+ \\
+ \\
+ \\
+ \\
+\end{array}$ \\
\hline $\begin{array}{l}\text { Gastrointestinal tract: } \\
\text { Stomach: glandular cells } \\
\quad \text { parietal cells } \\
\text { Small intestine: enterocytes, Paneth cells, goblet cells, Brunner's glands } \\
\text { Colon: enterocytes, goblet cells } \\
\text { Liver: hepatocytes } \\
\quad \text { bile duct cells } \\
\text { Gall bladder: mucosal cells }\end{array}$ & $\begin{array}{l}+ \\
+ \\
+ \\
+ \\
+ \\
+ \\
+\end{array}$ & $\begin{array}{l}+ \\
+ \\
+ \\
+ \\
+ \\
+ \\
+\end{array}$ \\
\hline $\begin{array}{l}\text { Respiratory and urogenital tract: } \\
\text { Trachea: tracheal epithelium, ciliated cells } \\
\text { Lung: pneumocytes, bronchial epithelium } \\
\text { Kidney: distal tubules, collecting ducts } \\
\quad \text { proximal tubules, Bowman's capsule } \\
\text { Bladder: transitional epithelium } \\
\text { Uterus: endometrial gland } \\
\text { Portio uteri: squamous epithelium } \\
\text { Testis: rete testis } \\
\text { germ epithelium } \\
\text { Placenta: amnion epithelium }\end{array}$ & $\begin{array}{l}+ \\
+ \\
+ \\
+ \\
+ \\
+ \\
+1- \\
+ \\
+ \\
+\end{array}$ & $\begin{array}{l}+ \\
+ \\
+ \\
+ \\
+ \\
+ \\
+ \\
+ \\
+\end{array}$ \\
\hline $\begin{array}{l}\text { Lymphoid tissues and skin: } \\
\text { Tonsils: crypt epithelia } \\
\quad \text { squamous epithelia } \\
\text { Thymus: cortical epithelia Hassall bodies } \\
\text { medullary epithelia } \\
\text { Skin: epidermis } \\
\text { sweat glands }\end{array}$ & $\begin{array}{l}+ \\
+1- \\
(+) \\
+ \\
- \\
+\end{array}$ & $\begin{array}{l}- \\
- \\
\text { ND } \\
\text { ND } \\
- \\
+\end{array}$ \\
\hline $\begin{array}{l}\text { Other tissues: } \\
\text { Spleen } \\
\text { Peripheral blood } \\
\text { Bone marrow } \\
\text { Brain } \\
\text { Connective tissue } \\
\text { Muscle: smooth } \\
\quad \text { striated }\end{array}$ & $\begin{array}{l}- \\
- \\
- \\
- \\
- \\
-\end{array}$ & $\begin{array}{l}- \\
- \\
- \\
- \\
- \\
- \\
-\end{array}$ \\
\hline $\begin{array}{l}\text { Heart } \\
\text { Endothelia } \\
\text { Myoepithelia } \\
\text { Mesothelia: pleura, peritoneum }\end{array}$ & $\begin{array}{l}\overline{-} \\
\overline{-}\end{array}$ & $\begin{array}{l}- \\
- \\
-\end{array}$ \\
\hline
\end{tabular}

Results obtained with APAAP immunostaining. + positive; (+) weak; + / - inhomogeneous; - negative; ND not detected.

the Ber-EP4 antigen, such as duct cells in breast, liver, and rete testis, constantly stained strongly in paraffin wax embedded sections; in other tissues reactivity was weak (lung and stomach) or completely absent (adrenal gland, prostate, tonsil and testis).

On paraffin wax sections of 49 epithelial tumours, Ber-EP4 gave consistent results for

Table 2 Reactivity of Ber-EP4 with human cell lines

\begin{tabular}{|c|c|c|}
\hline Origin & Cell line & Reactivity \\
\hline $\begin{array}{l}\text { Epithelial cells: } \\
\text { Breast carcinoma: }\end{array}$ & $\begin{array}{l}\text { MCF-7, MDA-MB-175, MDA-MB-231 } \\
\text { BT-20, AlAb }\end{array}$ & + \\
\hline $\begin{array}{l}\text { Colon carcinoma: } \\
\text { Pancreas carcinoma: } \\
\text { Vulva carcinoma: } \\
\text { Ovary carcinoma: } \\
\text { Total }\end{array}$ & 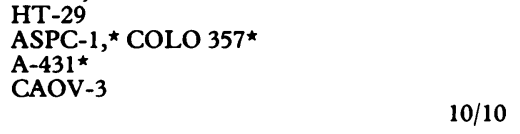 & $\begin{array}{l}+ \\
+ \\
+ \\
+ \\
+\end{array}$ \\
\hline $\begin{array}{l}\text { Non-epithelial cells } \\
\text { B cells: }\end{array}$ & $\begin{array}{l}\text { IM-9, CESS, Daudi, NALM } 12 \\
\text { U266, REH-6 }\end{array}$ & $\begin{array}{l}- \\
-\end{array}$ \\
\hline $\begin{array}{l}\text { Hairy cell leukemia: } \\
\text { T cells: }\end{array}$ & $\begin{array}{l}\text { JOK-1 } \\
\text { Jurkat, HSB-2, MOLT-4, MT-2 } \\
\text { HPB-ALL, HUT-102 }\end{array}$ & $\begin{array}{l}- \\
-\end{array}$ \\
\hline Hodgkin's disease: & $\begin{array}{l}\text { L } 540, \text { L } 591, \text { L } 428 \\
\text { KMH } 2, \mathrm{Co} \text { Ho }\end{array}$ & $\overline{-}$ \\
\hline Myeloid cells: & $\begin{array}{l}\text { HL-60, U937, THP-1, KG-1, DHL-1 } \\
\text { K562 }\end{array}$ & $\overline{+}$ \\
\hline $\begin{array}{l}\text { Neuroblastoma: } \\
\text { Rhabdomyosarcoma: } \\
\text { Total }\end{array}$ & $\begin{array}{l}\text { LAN }-5 \\
\text { RD }\end{array}$ & $\begin{array}{l}- \\
- \\
-\end{array}$ \\
\hline
\end{tabular}

Results determined with APAAP immunostaining. + positive; - negative.

$\star$ Tested with immunoperoxidase because of endogene alkaline phosphatase. tumours containing large amounts of the BerEP4 antigen-for example, breast and cholangiolar carcinomas (table 3). In carcinomas arising from tissues with no or smaller amounts of the Ber-EP4 antigen-hepatocellular and lung carcinoma-the antibody Ber-EP4 did not work satisfactorily. No reactivity was observed in non-epithelial tumours.

As no frozen material was available evaluation of diseased liver tissue with Ber-EP4 immunostaining was performed on paraffin wax embedded specimens of 15 livers with hepatitis of varying aetiology. In these cases pseudoductules and some hepatocytes adjacent to portal tracts showed a strong reaction with Ber-EP4, while bile ducts stained only weakly.

COMPARISON OF BER-EP4 and HEA125 MONOCLONAL ANTIBODIES

Sequential immunoprecipitation from ${ }^{125} \mathrm{I}$ or ${ }^{35}$ S-methionine labelled MCF-7 lysates with Ber-EP4 and HEA125 monoclonal antibodies showed that both precipitated the same antigen (figure 1). In cross-blocking experiments using K562 cells, HEA125 inhibited the binding of the FITC-labelled Ber-EP4 and vice versa. In cell and tissue binding studies HEA125 produced staining results identical with those seen with Ber-EP4. 
Table 3 Reactivity of Ber-EP4 with neoplastic frozen $(F)$ and paraffin wax embedded $(P)$ tissues

\begin{tabular}{|c|c|c|}
\hline \multirow[b]{2}{*}{ Tissue } & \multicolumn{2}{|c|}{ No of positive cases/Total No of cases } \\
\hline & $F$ & $P$ \\
\hline $\begin{array}{l}\text { Epithelial tumours } \\
\text { Primary carcinomas: } \\
\text { Breast: infiltrating ductal } \\
\quad \text { infiltrating lobular } \\
\text { Oesophagus: squamous } \\
\text { Stomach: adenocarcinoma } \\
\text { Colon: adenocarcinoma } \\
\text { Rectum: adenocarcinoma } \\
\text { Pancreas: adenocarcinoma } \\
\text { Kidney: renal cell } \\
\text { Liver: hepatocellular } \\
\text { cholangiolar } \\
\text { Lung: adenocarcinoma } \\
\quad \text { squamous } \\
\quad \text { oat cell } \\
\text { Thyroid gland: adenocarcinoma } \\
\text { Salivary gland: adenocarcinoma } \\
\text { Vagina: adenocarcinoma } \\
\text { Ovary: adenocarcinoma } \\
\text { Cervix uteri: squamous }\end{array}$ & $\begin{array}{c}9 / 9 \\
\text { nd } \\
4 / 4^{\star} \\
59 / 59 \\
19 / 19 \\
1 / 1 \\
10 / 10 \\
1 / 1 \\
4 / 6 \dagger \\
5 / 5 \\
3 / 3 \\
1 / 1 \\
\text { nd } \\
3 / 3 \\
1 / 1 \\
1 / 1 \\
1 / 1 \\
2 / 2\end{array}$ & $\begin{array}{c}22 / 22 \\
1 / 1 \\
\text { nd } \\
1 / 1 \\
2 / 2 \\
\text { nd } \\
\text { nd } \\
\text { nd } \\
1 / 6 \\
2 / 2 \\
3 / 6 \\
1 / 1 \\
4 / 5 \\
\text { nd } \\
\text { nd } \\
\text { nd } \\
\text { nd } \\
1 / 1\end{array}$ \\
\hline $\begin{array}{l}\text { Metastatic carcinomas: } \\
\text { Oesophagus: squamous } \\
\text { Stomach: adenocarcinoma } \\
\text { Colon: adenocarcinoma } \\
\text { Nasopharynx: undifferentiated } \\
\text { Pancreas: adenocarcinoma } \\
\text { Ovary: adenocarcinoma }\end{array}$ & $\begin{array}{l}1 / 1 \\
10 / 10 \\
3 / 3 \\
1 / 1 \\
1 / 1 \\
1 / 1\end{array}$ & $\begin{array}{l}\text { nd } \\
\text { nd } \\
\text { nd } \\
\text { nd } \\
\text { nd } \\
\text { nd }\end{array}$ \\
\hline $\begin{array}{l}\text { Others: } \\
\text { Appendix: appendix carcinoid } \\
\text { Pancreas: insulinoma } \\
\text { Total }\end{array}$ & $\begin{array}{l}\text { nd } \\
1 / 1 \\
142 / 144\end{array}$ & $\begin{array}{c}1 / 1 \\
1 / 1 \\
40 / 49\end{array}$ \\
\hline $\begin{array}{l}\text { Non-epithelial tumours } \\
\text { B cell lymphoma } \\
\text { T cell lymphoma } \\
\text { Hodgkin's disease } \\
\text { Leiomyoma } \\
\text { Sarcoma } \ddagger \\
\text { Malignant melanoma } \\
\text { Malignant fibrous histiocytoma } \\
\text { Malignant mesothelioma } \\
\text { Phaeochromocytoma } \\
\text { Total }\end{array}$ & $\begin{array}{l}0 / 34 \\
0 / 26 \\
0 / 4 \\
0 / 3 \\
0 / 6 \\
0 / 11 \\
0 / 1 \\
0 / 2 \\
0 / 1 \\
0 / 88\end{array}$ & $\begin{array}{c}0 / 3 \\
\text { nd } \\
\text { nd } \\
\text { nd } \\
\text { nd } \\
0 / 1 \\
\text { nd } \\
0 / 12 \\
\text { nd } \\
0 / 16\end{array}$ \\
\hline
\end{tabular}

Results determined with APAAP immunostaining.

^In one case of a carcinosarcoma reactivity only with the epithelial differentiated tumour component.

†Two cases negative, two cases partially negative.

+Fibrosarcoma, rhabdomyosarcoma, neurogen sarcoma and Ewing's sarcoma.

Table 4 Immunostaining of smears of serous effusions from pleura and peritoneum

\begin{tabular}{llc}
\hline & \multicolumn{2}{l}{ No of positive cases/Total No of cases } \\
\cline { 2 - 3 } Diagnosis & Ber-EP4 & $K L 1$ \\
\hline Carcinomatous effusions & $11 / 11$ & $7 / 7^{\star}$ \\
Reactive effusions & $0 / 25$ & $23 / 25^{\dagger}$ \\
\hline
\end{tabular}

Results determined with APAAP immunostaining

*Only seven cases due to lack of material.

$\uparrow$ Positive reaction due to labelling of mesothelial cells.

\section{Discussion}

Immunobiochemical investigations on the radiolabelled MCF-7 cell line showed that monoclonal antibody Ber-EP4 is directed against the protein moiety of two 34 kilodalton and 39 kilodalton glycopolypeptide chains, which are not covalently bound. Metabolic labelling with ${ }^{35} \mathrm{~S}$-methionine suggests a 39 kilodalton primary gene product for both chains.

Based on biochemical data, the Ber-EP4 antigen is different from all other known epithelial specific antigens except the HEA125 antigen (see below). The molecular weight and the basolateral localisation on the cell membrane distinguish the Ber-EP4 antigen from other surface antigens such as EMA, CEA, and related antigens. ${ }^{1213}$ Glycosylation and presence on the cell surface distinguish the Ber-EP4 antigen from cytokeratins. The reac- tivity of monoclonal antibody Ber-EP4 resembles that of the recently described HEA $125^{17} 18$ and $\mathrm{MH}^{37}$ antibodies. MH99, however, precipitates a molecule of different size. Our immunobiochemical investigations with BerEP4 and HEA125 antibodies showed identical results in sequential immunoprecipitations. Furthermore, cross-blocking experiments with flow cytometry on $\mathrm{K} 562$, an erythromyeloid cell line atypically expressing epithelial antigens such as cytokeratins, ${ }^{38}{ }^{39}$ and the BerEP4 antigen, showed that both antibodies are directed against a neighbouring or identical epitope of the same antigen. The strong positivity of the $\mathrm{K} 562$ cell line with both monoclonal antibodies is at variance with the results obtained with HEA125 in previous reports. ${ }^{18}$

In conclusion, the Ber-EP4 monoclonal antibody may be of value in: (i) the differential diagnosis of undifferentiated primary or metastatic tumours: (ii) the identification of bile duct cells in the diagnosis of liver diseases; (iii) the distinction between epithelial cells and normal, reactive, or neoplastic mesothelial cells.

All carcinomas, except some hepatocellular carcinomas, were positive with the Ber-EP4 monoclonal antibody, unlike all non-epithelial tumours tested. The antibody works reliably on frozen sections fixed in acetone, cytospins, and cell smears, whereas the epitope recognised by Ber-EP4 and HEA125 monoclonal antibodies can be destroyed by prolonged formalin fixation. Thus in paraffin wax embedded sections only a positive reaction with Ber-EP4 monoclonal antibody can be deemed a reliable result.

The lack of Ber-EP4 antigen expression in hepatocytes is particularly interesting. In normal liver Ber-EP4 stains only bile duct cells but not hepatocytes, similar to antibodies against cytokeratins 7 and $19 .^{40}$ This should prove useful in the diagnosis of innate bile duct hypoplasia and diseases accompanied by either destruction or proliferation of bile ducts.

Most importantly Ber-EP4 monoclonal antibody does not react with normal or reactive mesothelial cells. The antibody can therefore be used for the differential diagnosis between mesothelial cells and carcinoma cells, particularly in smears of serous effusions. Anticytokeratin monoclonal antibodies are not helpful in this respect because of their reactivity with mesothelial cells. Anti-CEA antibodies and Leu-Ml and B72.3 have been reported to help in the discrimination of carcinoma cells and reactive or malignant transformed mesothelial cells because of their unreactivity with the latter cell type. ${ }^{41}$ These antibodies, however, are not consistently reactive with all carcinomas and Leu-Ml also stains non-epithelial cells.

Ber-EP4 might also be useful in the differential diagnosis of malignant mesotheliomas. The series investigated in this paper, however (two cases on cryostat sections), is too small to answer conclusively, this question.

The function of the Ber-EP4 antigen is unknown. The broad reactivity of monoclonal 
antibody Ber-EP4 with almost all carcinomas, irrespective of the grade of differentiation, suggests an essential functional role for this antigen in epithelial cells.

We thank Dr Horst Dürkop for advice in internal labelling experiments, Dr Barbara Fleige, and Dr Carl-Alexander Hartmann for help in selecting lung biopsy specimens and smears of serous effusions, and Dr Hebst for critical reading of the manuscript.

This work is part of the doctoral thesis of Ute Latza and was supported by a postgraduate grant (NaFöG) and by "Deutsche Krebshilfe".

1 Gatter KC, Alcock C, Heryet A, Mason DY. Clinical importance of analysing malignant tumours of uncertain origin with immunohistological techniques. Lancet 1985;i:1302-5.

2 Damjanow I, Knowles BB. Biology of disease: monoclonal antibodies and tumor-associated antigens. Lab Invest 1983;48:510-25.

3 Gatter KC, Abdulaziz Z, Beverly P, et al. Use of monoclonal antibodies for the histopathological diagnosis of human malignancy. J Clin Pathol 1982;35:1253-67.

4 Lauder I, Holland D, Mason DY, Gowland G, Cunliffe WJ. Identification of large cell undifferentiated tumors in lymph nodes using leukocyte common and keratin antibodies. Histopathology 1984;8:259-72.

5 Cooper D, Schermer A, Sun T-T. Biology of disease: classification of human epithelia and their neoplasms using monoclonal antibodies to keratins: strategies, applications, and limitations. Lab Invest 1985;52:243-56.

6 Osborn M, Weber $K$. Tumor diagnosis by intermediate filament typing: a novel tool for surgical pathology. Lab Invest 1983;48:372-94.

7 Kasper M, Karsten U. Coexpression of cytokeratin and vimentin in Rathke's cysts of human pituitary gland. Cell Tissue Res 1988;253:419-24.

8 Gröne H-J, Weber K, Gröne E, Helmchen U, Osborn M Coexpression of keratin and vimentin in damaged and Coexpression of keratin and vimentin in damaged and regenerating tub $1987 ; 129: 1-8$.

9 Henzen-Logmans SC, Mullink H, Ramackers FCS Tadema T, Meijer CJLM. Expression of cytokeratins and vimentin in epithelial cells of normal and pathological thyroid tissue. Virchows Arch (Cell Pathol) 1987;410: 347-54.

10 Domagala W, Weber K, Osborn M. Diagnostic significance of coexpression of intermediate filaments in fine needle

11 Milani S, Herbst H, Schuppan D, et al. Vimentin expressio in proliferating bile duct epithelia. Virchow Arch (Pathol Anat) 1989;415:237-42.

12 Wagner $\mathrm{C}$, Breuer $\mathrm{H}$. Biochemical and immunochemical aspects of carcinoembryonic antigen (CEA) and CEA related antigens: current status and future perspectives. $J$ Clin Chem Clin Biochem 1982;20:705-12.

13 Cordell J, Richardson TC, Pulford KAF et al. Production of monoclonal antibodies against human epithelial membrane antigen for use in diagnostic immunocytochemistry. Br J Cancer 1985;52:347-54.

14 Edwards PAW. Heterogenous expression of cell-surface antigens in normal epithelia and their tumours, revealed by monoclonal antibodies. Br J Cancer 1985;51:149-60.

15 Delsol G, Stein H, Pulford KAF, Gatter KC, Erber WN, Zinne K. Human lymphoid cells express epithelial membrane antigen. Lancet 1984;ii:1124-8.

16 Gosh AK, Gatter KC, Dunnhill MS, Mason DY. Immunohistological staining of reactive mesothelium mesothelioma, and lung carcinoma with a panel of monoclonal antibodies. J Clin Pathol 1987;40:19-25.

17 Momburg F, Moldenhauer G, Hämmerling GJ, Möller P. Immunohistochemical study of the expression of a $M$ 34,000 human epithelium-specific surface glycoprotein in normal and malignant tissues. Cancer Res 1987;47: 2883-91.

18 Moldenhauer G, Momburg F, Möller P, Schwartz R, Hämmerling GJ. Epithelium-specific surface glycoprotein of $M_{r} 34,000$ is a widely distributed human carcinoma marker. Br J Cancer 1987;56:714-21.

19 Dippold WG, Klingel R, Bernhard H, Dienes H-P, Knuth
A, Meyer zum Büschenfelde K-H. Epithelial cell marker on gastrointestinal tumors and in human secretion defined by a monoclonal antibody. Cancer Res 1987;47:2092-7.

20 Jones DB, Scott CS, Wright DH et al. Phenotypic analysis of an established cell line derived from a patient with Hodgkin's disease (HD). Haematol Oncol 1985;3:133-45.

21 Kamesaki H, Fukuhara S, Tatsumi E, et al. Cytochemical, immunological, chromosomal and molecular genetic analysis of a novel cell line derived from Hodgkin' disease. Blood 1986;68:285.

22 Diehl V, Kirchner HH, Schaadt M, Fonatsch C, Stein $H_{\text {, }}$ Gerdes J, Boie C. Hodgkin's disease: establishment of four in vitro cell lines. J Cancer Res Clin Oncol 1981;101 111-24.

23 Diehl V, Kirchner HH, Burrichter H, et al. Characteristics of Hodgkin's disease derived cell lines. Cancer Treat Rep 1982;66:615-32.

24 Cordell J, Falini B, Erber WW, et al. Immunoenzymatic labelling of monoclonal antibodies with immune complexes of alkaline phosphatase and monoclonal antialkaline phosphatase (APAAP) complexes. $J$ Histochem Cytochem 1984;32:219-29.

25 Stein H, Gatter KC, Asbahr H, Mason DY. Methods in Laboratory Investigation. Use of freeze-dried paraffinembedded sections for immunohistologic staining with monoclonal antibodies. Lab Invest 1985;52:676-83.

26 Stein H, Gerdes J, Schwab U, et al. Identification of Hodgkin and Sternberg-Reed cells as a unique cell type derived from a newly detected small cell population. Int $J$ Cancer 1980;30:445-59.

27 Köhler G, Milstein C. Continous culture of fused cells secreting antibody of predefined specificity. Nature 1975 32:495-7.

$28 \mathrm{Oi}$ VT, Herzenberg LA. Immunoglobulin-producing hybrid cell lines. In: Mishell BB, Shiigi SM, eds. Selected methods in cellular immunology. San Francisco: Freeman 1980:351-72.

29 Thorell Y, Johansson BG. Enzymatic iodination of polypeptides with ${ }^{125} \mathrm{~J}$ to high specific activity. Biochem Biophys Acta 1971;251:363.

30 Wano Y, Uchiyama T, Fukuki K, Maeda M, Uchino H, Yodo J. Characterization of human interleukin 2 receptor (Tac antigen) in normal and leukemic $T$ cells: coexpresion of normal and aberrant receptors on Hut-102 expression of normal and aberrant

31 Schwarting R, Stein H, Chang Yi Wang. The monoclonal antibodies aS-HCLl (aLeu-14) and aS-HCL3 (aLeuM5) allow the diagnosis of hairy cell leukemia. Blood 1985;65:974.

32 Laemmli UK. Cleavage of structural proteins during the assembly of the head of bacteriophage T4. Nature 1970;277:680.

33 Schwarting R, Gedes J, Stein H. BER-H2: a new monoclonal antibody of the $\mathrm{Ki}-1$ family for the detection of Hodgkin's disease in formalin-fixed tissue sections (A2.13). In: McMichael AJ, ed. Leucocyte typing III, white cell differentiation antigens. Oxford: Oxford University cell differentiation an

34 Thotakura NR, Bahl OP. Enzymatic deglycosylation of glycoproteins. Methods in Enzymology 1985;138:350-9.

35 Woodward MP, Young WW, Bloodgood RA. Detection of monoclonal antibodies specific for carbohydrate epitopes using periodate oxidation. J Immunol Methods 1985; 78:143-53.

36 Stefani M, DeMartino C, Zamboni L. Fixation of ejaculated spermatazoa for electron microscopy. Nature 1967;216:173-4.

37 Cordon-Cardo C, Mattes MJ, Melamed MR, Lewis JL, Jr Old LJ, Lloyd KO. Immunopathologic analysis of a pane of mouse monoclonal antibodies reacting with human ovarian carcinomas and other human tumors. Int $J$ ovarian carcinomas and other
Gynecol Pathol 1985;4:121-30.

38 Lozzio CB, Lozzio BB. Human chronic myelogenous leukemia cell line with positive Philadelphia chromosome. Blood 1975;45:321-34.

39 Zauli D, Gobbi M, Crespi C, et al. Vimentin and keratin intermediate filaments expression by $\mathrm{K} 562$ leukemic cell line. Leuk Res 1986;10:29-33.

40 Van Eyken P, Sciot R, Van Damme B, de Wolf-Peeters C, Desmet VJ. Keratin immunohistochemistry in normal human liver. Cytokeratin pattern of hepatocytes, bile ducts and acinar gradient. Virchows Arch (Cell Pathol) ducts and acinar

41 Warnock ML, Stoloff A, Thor A. Differentiation of adenocarcinoma of the lung from mesothelioma: periodic acidSchiff, monoclonal antibodies B72.3, and Leu M1. Am J Pathol 1988;133:30-8. 